\title{
Оптический журнал
}

DOI: 10.17586/1023-5086-2022-89-03-03-04

\section{Голографические технологии сегодня и завтра}

\author{
ВЛАДИМИР ЮРЬЕВИЧ ВЕНЕДИКТОВ, ДОКТОР ФИЗ.-МАТ. НАУК \\ Санкт-Петербургский государственный электротехнический университет \\ «ЛЭТИ им. В.И. Ульянова (Ленина)»
}

В 2022 г. человечество отмечает семидесятипятилетний юбилей открытия Д. Габором голографии. Несмотря на столь солидный возраст, голография как наука продолжает активно развиваться. В то же время сегодня многие отрасли оптической промышленности и ряда других отраслей немыслимы без применения уже разработанных и вновь создаваемых голографических технологий. Во многих современных изображающих и спектральных приборах используются различные голограммные оптические элементы. Голографическая запись дифракционных решеток, по сути дела, вытеснила другие методы создания решеток.

Активно развиваются новые методы цифровой и компьютерной голографии, которые находят свое применение в голографическом хранении информации, в сжатии данных, в голографической интерферометрии, а также в технологиях защиты информации от копирования и защиты потребителей от контрафактной продукции.

Следует отметить, что в перечисленных областях науки и технологии российские ученые по-прежнему являются одними из лидеров. Появляются и совершенно новые идеи и технологии, в частности, технологии измерения волнового фронта с помощью голографических датчиков. В самые последние годы достигнут большой прогресс в создании систем дополненной реальности и голографических визиров как общегражданского, так и специального назначения.
Еще одна интересная тенденция, наметившаяся в последние годы (и, к сожалению, пока не получившая должного развития в России) - возврат к идеям Габора, выдвинутым в еще долазерную эпоху, а именно развитие методов низкокогерентной голографии и, в частности, голографической низкокогерентной микроскопии.

Вниманию читателей «Оптического журнала» предлагается специальный выпуск, посвященный различным аспектам современной голографии и прикладных оптических технологий, среди которых можно выделить следующие наиболее актуальные направления оптической голографии.

В области защитной голографии - методы работы с фотополимерными материалами для оптической персонализации с помощью компьютерно-синтезированных голограмм в условиях тиражной записи, для реализации полноцветных и цветных объемных изображений.

В области создания дифракционных и голограммных оптических элементов - задача повышения дифракционной эффективности в условиях технологичности их производства. Актуальны исследования объемных дифракционных решеток для широкого класса задач: от реализации перестраиваемых лазерных систем до световодов устройств дополненной реальности.

Методы цифровой голографии для развития оптического кодирования информации, голографического формирования 3D изобра- 
жений, создания оптических ловушек и других фотонных устройств.

Контроль качества оптических поверхностей в оптической промышленности. Необходимо внесение интерферометров для решения этой задачи в государственный реестр средств из- мерений. Требуется технологический прорыв в реализации бесконтактного контроля оптических поверхностей.

Эта тематика нашла свое отражение в публикуемых статьях.

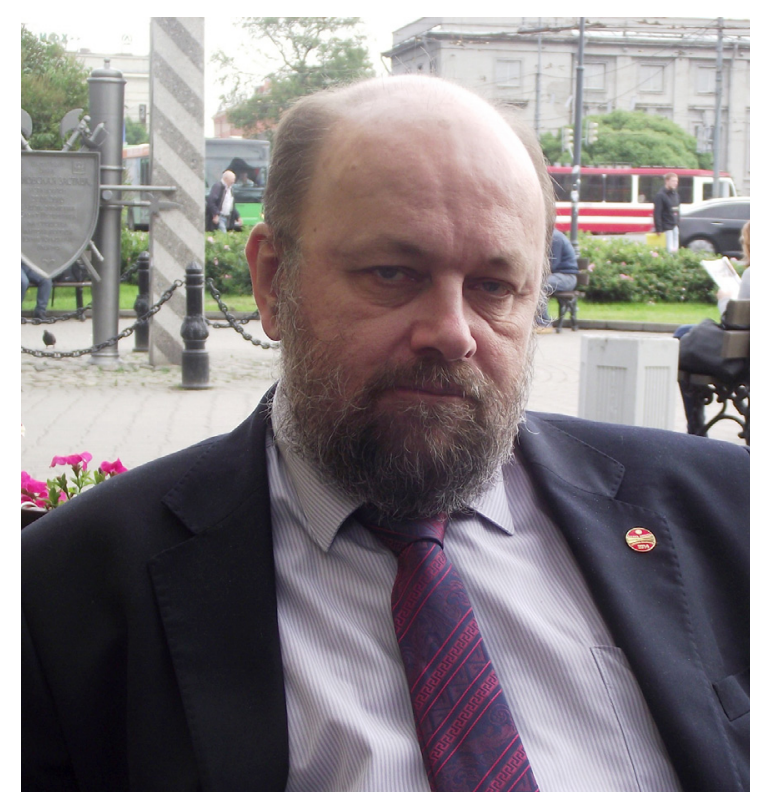

Венедиктов Владимир Юръевич - окончил физический факультет Ленинградского государственного университета им. А.А. ЗЖданова в 1982 г. С 1982 по 2015 г. работал в Государственном оптическом институте им. С.И. Вавилова, где прошел путь от стажера-исследователя до начальника лаборатории адаптивной оптики. В 2003 г. получил ученую степень кандидата физико-математических наук по специальности «Оптика», в 2006 г. - ученое звание «доцент» по той же специальности и в 2012 г. защитил диссертацию на соискание ученой степени доктора физикоматематических наук также по специальности «Оптика». С 2006 г. работает в СПбГЭТУ «ЛЭТИ», в настоящее время в должности главного научного сотрудника и профессора кафедры Лазерных измерительных и навигационных систем. Также является профессором физического факультета Санкт-Петербургского государственного университета.

Ведущий российский специалист в области голографии, адаптивной и сингулярной оптики, оптических резонаторов, а также оптической интерферометрии и гироскопии. Опубликовал более 200 научных и учебно-методических трудов, в том числе более 70 статей в ведущих рецензируемых журналах. Автор четырех коллективных монографий и 12 авторских свидетельств СССР и патентов РФ. 